ESAU AND JACOB 



\title{
ESAU AND JACOB
}

\author{
by \\ MACHADO DE ASSIS
}

Translated, with an Introduction, by

Helen Caldwell

University of California Press

Berkeley and Los Angeles

1965 
University of California Press

Berkeley and Los Angeles, California

(C) 1965 by The Regents of the University of California

Published with the assistance of a grant from the

Rockefeller Foundation

Library of Congress Catalog Card No.: 65-19249

Designed by Ann W. Hawkins

Manufactured in the United States of America 